\title{
Jaki korporatyzm w Polsce? Rada Dialogu Społecznego w okresie funkcjonowania rządu Beaty Szydło
}

\begin{abstract}
Streszczenie: Korporatyzm rozumiany jako system formułowania polityki, w ramach którego rząd, związki zawodowe i organizacje pracodawców wspólnie podejmują i implementują decyzje polityczne w obszarze społeczno-gospodarczym, występuje w wielu państwach Europy Zachodniej. Po 1989 roku w Polsce wykształciła się zdeformowana odmiana tego systemu - PR (Public Relations) korporatyzm. W jego ramach rząd pozoruje negocjacje trójstronne z partnerami społecznymi, aby zwiększyć poziom poparcia politycznego wśród obywateli. W rzeczywistości samodzielnie podejmuje decyzje polityczne.

Celem artykułu było zbadanie czy utworzenie nowego organu korporatystycznego (Rady Dialogu Społecznego), dysponującego znacząco większymi kompetencjami niż poprzednik (Trójstronna Komisja ds. Społeczno-Gospodarczych) doprowadziło do transformacji systemu uprawiania polityki w Polsce z PR korporatyzmu na korporatyzm zachodnioeuropejski.

W artykule poddano analizie porównawczej aktywność Rady w okresie funkcjonowania rządu Beaty Szydło (2015-2017) z działalnością Komisji w latach 2002-2015. Wyniki badań ujawniły, że Rada i Komisja były równie nieefektywnymi organami dialogu społecznego, na forum których nie były podejmowane istotne decyzje polityczne. W artykule wykazano, że zwiększenie uprawnień organu korporatystycznego nie musi powodować poprawy jakości dialogu społecznego. Po 2015 roku PR korporatyzm pozostał dominującym systemem formułowania polityki w Polsce.
\end{abstract}

Słowa kluczowe: korporatyzm, PR korporatyzm, Rada Dialogu Społecznego, Trójstronna Komisja ds. Społeczno-Gospodarczych, partnerzy społeczni, rząd

\section{Wprowadzenie}

orporatyzm to system uprawiania polityki, w ramach którego reprezentatywne Zzwiązki zawodowe, organizacje pracodawców oraz rząd - w drodze trójstronnych negocjacji - wspólnie podejmują decyzje polityczne w obszarze społeczno-gospodarczym, a następnie razem wdrażają je w życie. Obejmuje on „m.in. polityki: płacową, cenową, zatrudnienia, fiskalną, podatkową i społeczną" (Herbut, 2003, s. 20). Korporatyzm był dominującym systemem formułowania polityki w wielu demokratycznych państwach Europy Zachodniej po 1945 roku. Warto podkreślić, że również w XXI wieku, m.in. rządy Austrii, Belgii, Danii, Finlandii, Grecji i Holandii zawierały z partnerami społecznymi pakty społeczne ${ }^{1}$ regulujące wspomniane powyżej obszary polityki (Donaghey, Teague, 2005, s. 491).

${ }^{1}$ Przez pakt społeczny należy rozumieć ,publicznie ogłoszony kontrakt pomiędzy rządem a partnerami społecznymi dotyczący różnych sfer polityki ekonomicznej kraju, w ramach którego dokładnie zidentyfikowano cele polityczne, środki niezbędne do ich osiągnięcia oraz zadania i obowiązki sygnatariuszy" (Olejnik, 2017, s. 63). 
Po 1989 roku powstały liczne opracowania naukowe poświęcone analizie relacji istniejących między rządem, związkami zawodowymi i organizacjami pracodawców w Polsce w okresie poprzedzającym ich instytucjonalizację (1989-1993), jak i po utworzeniu Trójstronnej Komisji ds. Społeczno-Gospodarczych (zwanej dalej Komisją) (1994-2015) (np. Gardawski, 2009; Ost, 2010; Towalski, 2011). Badacze jednoznacznie stwierdzili, że - poza nielicznymi wyjątkami (np. zawarciem Paktu o Przedsiębiorstwie Państwowym w Trakcie Przekształcenia w 1993 roku) - polski dialog społeczny nie przybrał formy zachodnioeuropejskiego korporatyzmu (Ost, 2010, s. 93 i 106). Wygenerował zaś jego alternatywną wersję, zwaną przez Magdalenę Bernaciak PR (Public Relations) korporatyzmem (Bernaciak, 2013). W ramach PR korporatyzmu rząd prowadzi trójstronne negocjacje wyłącznie dla celów pijarowych, tzn. aby udowodnić przed obywatelami, że wsłuchuje się w opinie różnych grup społecznych i jest otwarty na ich inicjatywy. Działania te mają prowadzić do zwiększenia poparcia politycznego dla rządu. W rzeczywistości odrzuca on propozycje partnerów społecznych, decyzje polityczne podejmuje zaś w sposób unilateralny (Bernaciak, 2013, s. 247).

Zasadnicza różnica między zachodnioeuropejskim a PR korporatyzmem polega więc na tym, że w ramach pierwszej wersji korporatyzmu rząd prowadzi negocjacje trójstronne z partnerami społecznymi w celu uzgodnienia wspólnej polityki społeczno-gospodarczej, podczas gdy w obrębie drugiego modelu rząd traktuje dialog społeczny jedynie jako narzędzie służące do poprawienia swoich notowań politycznych i skanalizowania niezadowolenia społecznego różnych grup zawodowych wobec wyznaczanej przez niego w sposób autonomiczny polityki społeczno-gospodarczej.

Nie zostały dotychczas przeprowadzone badania naukowe dotyczące wpływu nowej, dysponującej znacząco większymi kompetencjami niż Komisja, instytucji trójstronnej - Rady Dialogu Społecznego (zwanej dalej Radą) - na kształt systemu formułowania polityki w Polsce. Niniejszy artykuł ma na celu wypełnienie tej luki badawczej. Zagadnienie to jest o tyle ważne, że zdaniem liderów związków zawodowych i organizacji pracodawców niska efektywność dialogu społecznego w Polsce - w porównaniu do państw Europy Zachodniej - była spowodowana zbyt małymi kompetencjami Komisji. Według nich remedium na te problemy miało być zastąpienie Komisji inną, wzbogaconą o dodatkowe kompetencje, instytucją korporatystyczną (Gardawski, 2014). W 2015 roku na mocy ustawy o Radzie Dialogu Społecznego i innych instytucjach dialogu społecznego (zwanej dalej ustawą o Radzie) takie właśnie ciało - Rada - zostało utworzone.

W artykule została sformułowana hipoteza badawcza, przy pomocy której zweryfikowano wspomniane powyżej twierdzenia partnerów społecznych: utworzenie silnego, dysponującego szerokimi kompetencjami organu korporatystycznego spowoduje transformację systemu uprawiania polityki w Polsce z PR korporatyzmu na model korporatyzmu zbliżony do zachodnioeuropejskich wzorców.

Dla celów artykułu poddano analizie porównawczej aktywność Rady w okresie funkcjonowania rządu Beaty Szydło (16 listopada 2015-11 grudnia 2017) z działalnością Komisji w latach 2002-2015. Między Radą i Komisją występowały 2 relewantne jakościowe podobieństwa, które umożliwiły zastosowanie metody komparatywnej (Chodubski, 2006, s. 125) pozwalającej na określenie różnic w zakresie efektywności działania tych instytucji. Jedno z nich dotyczyło umocowania prawnego Rady i Komisji. Kompetencje obu organów były regulowane na poziomie ustawowym: ustawy o Radzie oraz ustawy 
o Trójstronnej Komisji do Spraw Społeczno-Gospodarczych i wojewódzkich komisjach dialogu społecznego (zwanej dalej ustawą o Komisji). Kolejne podobieństwo odnosiło się do składu obu ciał. Dokładnie te same związki zawodowe i organizacje pracodawców należały do Komisji w latach 2002-2015 oraz do Rady w latach 2015-2017.

\section{Rada vs. Komisja - skład, struktura i kompetencje}

W skład Rady wchodzą przedstawiciele strony rządowej oraz stron pracowników i pracodawców, na które składają się związki zawodowe i organizacje pracodawców spełniające określone w ustawie o Radzie kryteria reprezentatywności. Za reprezentatywne związki zawodowe uznaje się ogólnokrajowe organizacje związkowe bądź federacje lub konfederacje związków zawodowych zrzeszające co najmniej 300000 pracowników, które działają w więcej niż w połowie sekcji Polskiej Klasyfikacji Działalności [PKD] (art. 23 ustawy o RDS). Do grona reprezentatywnych stowarzyszeń pracodawców zaliczano natomiast ogólnokrajowe organizacje pracodawców posiadające wśród swych członków regionalne, ponadbranżowe organizacje działające w co najmniej połowie województw. Każda reprezentatywna organizacja pracodawców musi zrzeszać pracodawców prowadzących działalność gospodarczą w co najmniej połowie sekcji PKD, którzy zatrudniają więcej niż 300000 pracowników (art. 24 ustawy o Radzie). Zarówno w przypadku związków zawodowych, jak i stowarzyszeń pracodawców przy ustalaniu kryterium liczebności organizacje te nie mogły uwzględnić więcej niż 100000 pracowników zatrudnionych w podmiotach, których podstawowy rodzaj działalności jest określony w jednej sekcji PKD (art. 23 i 24 ustawy o Radzie). Niemal tożsame kryteria reprezentatywności obowiązywały partnerów społecznych chcących należeć do Komisji po 2001 roku (art. 6 i 7 ustawy o Komisji). Te same organizacje związkowe (NSZZ Solidarność, Ogólnopolskie Porozumienie Związków Zawodowych [OPZZ], Forum Związków Zawodowych [FZZ]) i stowarzyszenia pracodawców (Związek Pracodawców Business Centre Club [ZP BCC], Konfederacja „Lewiatan”, Związek Rzemiosła Polskiego i Pracodawcy Rzeczypospolitej Polskiej) spełniały ww. warunki i były członkami Komisji oraz Rady (w latach 2015-2017).

Struktura Rady jest zbliżona do struktury Komisji. Instytucje te obradowały na posiedzeniach plenarnych. $\mathrm{W}$ ich ramach mogły być zakładane zespoły problemowe, którym członkowie instytucji przydzielali konkretne sprawy do rozpatrzenia. Pracami obu organów kierowało prezydium, do którego należeli reprezentanci rządu oraz wszystkich organizacji wchodzących w skład tych ciał, złożone z przewodniczącego i wiceprzewodniczących Komisji/Rady. Między Komisją a Radą występowała 1 istotna strukturalna różnica. Przewodniczącym Komisji był zawsze członek rządu (art. 12 ustawy o Komisji), który sprawował tę funkcję aż do odwołania przez premiera. W przypadku Rady kadencja przewodniczącego trwa 1 rok. Jest ona sprawowana naprzemiennie przez przedstawiciela strony pracowników, pracodawców i rządu (art. 32 ustawy o Radzie). Zmiana ta ma fundamentalne znaczenie. Dzięki niej partnerzy społeczni uzyskali duży wpływ na sposób funkcjonowania Rady (m.in. przewodniczący zwołuje oraz kieruje posiedzeniami Rady i prezydium).

Na forum Komisji oraz Rady mogły być rozpatrywane wszystkie sprawy o dużym znaczeniu społeczno-gospodarczym. Partnerzy społeczni mieli znaczące uprawnienia 
do formułowania agendy programowej obu instytucji - zarówno w przypadku Komisji, jak i Rady każda ze stron mogła wprowadzić pod obrady jakąkolwiek kwestię, która jej zdaniem oddziaływała w istotny sposób na stan gospodarki państwa (art. 2 ustawy o Komisji, art. 4 ustawy o Radzie). Komisja oraz Rada miały ponadto uprawnienia do opiniowania przygotowywanych przez Radę Ministrów projektów założeń projektów ustaw, projektów aktów prawnych, projektu budżetu państwa i innych projektów dokumentów rządowych; oraz opiniowania wysokości wskaźnika emerytur i rent z Funduszu Ubezpieczeń Społecznych i średniorocznego wskaźnika wynagrodzeń w państwowej sferze budżetowej; a także opiniowania wysokości płacy minimalnej oraz świadczeń rodzinnych i świadczeń pieniężnych z tytułu pomocy społecznej (Olejnik, 2017, s. 302; ustawa o Radzie; ustawa o Komisji).

Komisja oraz Rada wyrażały stanowisko w postaci uchwał trójstronnych. Chociaż nie niosły one za sobą skutków prawnych to i tak wywierały duży wpływ na kondycję dialogu społecznego w Polsce. Składały się bowiem na nie treści dotyczące konkretnych polityk publicznych dobrowolnie popartych przez rząd, który dysponował uprawnieniami do wprowadzenia ich w życie. Strona rządowa w większości przypadków decydowała się na przestrzeganie tych porozumien. W przeciwnym wypadku partnerzy społeczni mogliby zrezygnować $\mathrm{z}$ członkostwa $\mathrm{w}$ tych instytucjach, ponieważ zyskaliby świadomość, że efekty ich pracy nie mają przełożenia na politykę państwa.

Rada oraz Komisja różniły się między sobą w kwestii sposobu podejmowania uchwał trójstronnych. Przyjęcie uchwały przez Komisję wymagało zgody rządu oraz wszystkich organizacji, które brały udział w głosowaniu (art. 10 ustawy o Komisji). Rada przyjmuje natomiast uchwałę, jeżeli wszystkie jej strony wyrażą na to zgodę. Stanowisko strony pracowników i strony pracodawców w sprawie uchwały jest „przyjmowane zwykłą większością, przy czym wymagane jest uczestniczenie [w głosowaniu] co najmniej 2/3 członków Rady reprezentujących daną stronę" (art. 28 ustawy o Radzie). Oznacza to, że w kontraście do Komisji, Rada może przyjmować uchwały przy sprzeciwie (biorąc pod uwagę liczbę związków zawodowych i organizacji pracodawców w niej zasiadających) 1 organizacji związkowej i 1 stowarzyszenia pracodawców. Takie rozwiązanie jest korzystne z punktu widzenia efektywności działania instytucji, gdyż uniemożliwia 1 organizacji zablokowanie prac nad ważnymi projektami, do czego dochodziło w ramach Komisji.

W przeciwieństwie do Komisji w ramach Rady strony pracowników i pracodawców miały prawo podejmować uchwały dwustronne ${ }^{2}$. Na potrzeby artykułu wyróżniono 2 typy uchwał dwustronnych, które partnerzy społeczni byli władni przyjmować: uchwały opiniodawcze i uchwały inicjujące proces polityczny. W ramach pierwszego rodzaju uchwał strony pracowników i pracodawców głównie wyrażały sprzeciw wobec planów politycznych rządu. Władze państwowe nie musiały jednak reagować na sugestie członków Rady. W związku z tym można stwierdzić, że partnerzy społeczni w ograniczony sposób mogli wpływać na politykę rządu poprzez te uchwały.

$\mathrm{W}$ drodze uchwał inicjujących proces polityczny strony pracowników i pracodawców mogły zaś: po pierwsze, przekazywać projekty założeń projektów ustaw i projekty

${ }^{2}$ Uchwała dwustronna jest przyjmowana, jeżeli strony pracowników i pracodawców wyrażą na nią zgodę. Stanowisko strony pracowników i pracodawców jest ustalane w ten sam sposób, co w przypadku głosowania nad uchwałami trójstronnymi. 
aktów prawnych w obszarze społeczno-gospodarczym właściwemu ministrowi w celu przedłożenia Radzie Ministrów (art. 7 ustawy o Radzie); po drugie, składać wniosek o zorganizowanie wysłuchania publicznego do instytucji odpowiedzialnej za przygotowanie aktu normatywnego dotyczącego polityki społeczno-gospodarczej państwa (art. 8 ustawy o Radzie); po trzecie, przedstawić zapytanie w zakresie spraw społeczno-gospodarczych do właściwego ministra (art. 9 ustawy o Radzie), po czwarte, występować z wnioskiem o zmianę ustawy lub innego aktu prawnego do właściwego ministra (art. 13 ustawy o Radzie); po piąte, występować z wnioskiem do Sądu Najwyższego o rozstrzygnięcie konkretnego zagadnienia prawnego (art. 14 ustawy o Radzie). Adresaci uchwał (z wyjątkiem Sądu Najwyższego) byli zobligowani do udzielenia odpowiedzi na ich treść w określonym ustawowo terminie. Nie ulega zatem wątpliwości, że uchwały inicjujące proces polityczny ułatwiały partnerom społecznym wzięcie udziału w procesie stanowienia oraz implementacji prawa. Ponadto, poprzez nie partnerzy społeczni mogli wymuszać na rządzie prowadzenie dialogu społecznego, gdyby ten dążył do ograniczenia swojej aktywności na forum Rady.

W porównaniu do Komisji, Rada cieszy się znaczącą niezależnością finansową. Wydatki Komisji były opłacane ad hoc z budżetu państwa, natomiast Rada dysponuje oddzielnym budżetem (Czarzasty, 2015), dzięki czemu jest w stanie planować swoje wydatki z wyprzedzeniem, np. może nawiązać współpracę z ekspertami specjalizującymi się w sprawach społeczno-gospodarczych będących przedmiotem rozmów Rady. Zmiana ta miała m.in. pomóc partnerom społecznym w opracowaniu własnych projektów ustaw, które następnie byłyby przekazywane (poprzez uchwały inicjujące proces polityczny) Radzie Ministrów.

Reasumując, na podstawie zebranych w tej części artykułu informacji można stwierdzić, że Rada zapewniała partnerom społecznym większe możliwości wpływania na kształt polityki gospodarczej rządu niż Komisja.

\section{Rada w okresie funkcjonowania rządu Beaty Szydło a Komisja w latach 2002-2015. Analiza porównawcza}

W porównaniu do Komisji, Radę cechowała ponadprzeciętna aktywność w zakresie zwoływania posiedzeń plenarnych oraz posiedzeń prezydium i zespołów problemowych. Potwierdzają to dane dotyczące częstotliwości posiedzeń ciał Komisji i Rady zamieszczone w tabeli 1 i 2.

Tabela 1

Liczba posiedzeń plenarnych, zespołów problemowych oraz prezydium Komisji w latach 2002-2015

\begin{tabular}{|c|c|c|c||}
\hline Rok & $\begin{array}{c}\text { Liczba posiedzeń } \\
\text { plenarnych }\end{array}$ & $\begin{array}{c}\text { Liczba posiedzeń zespolów } \\
\text { problemowych }\end{array}$ & $\begin{array}{c}\text { Liczba posiedzeń } \\
\text { prezydium }\end{array}$ \\
\hline 1 & 2 & 3 & 4 \\
\hline 2002 & 10 & 54 & 26 \\
\hline 2003 & 9 & 73 & 28 \\
\hline 2004 & 7 & 58 & 26 \\
\hline 2005 & 5 & 32 & 11 \\
\hline
\end{tabular}




\begin{tabular}{|c|c|c|c|}
\hline 1 & 2 & 3 & 4 \\
\hline 2006 & 5 & 36 & 18 \\
\hline 2007 & 4 & 57 & 15 \\
\hline 2008 & 8 & 100 & 19 \\
\hline 2009 & 7 & 77 & 14 \\
\hline 2010 & 5 & 57 & 7 \\
\hline 2011 & 6 & 56 & 5 \\
\hline 2012 & 8 & 59 & 8 \\
\hline 2013 & 8 & 32 & 5 \\
\hline 2014 & 5 & 27 & brak danych \\
\hline 2015 & brak danych & brak danych & \multicolumn{2}{c}{} \\
\hline
\end{tabular}

Źródło: Opracowanie własne na podstawie Ministerstwo Pracy i Polityki Społecznej, Trójstronna Komisja do Spraw Społeczno-Gospodarczych. Informator za rok 2013, Biblioteka Dialogu Społecznego, Warszawa 2014, s. 81; Ministerstwo Pracy i Polityki Społecznej, Instytucje dialogu społecznego przy urzędach administracji rzadowej. Informator za rok 2014, Biblioteka Dialogu Społecznego, Warszawa 2015, s. $19-37$.

Tabela 2

\section{Liczba posiedzeń plenarnych, zespołów problemowych oraz prezydium Rady} w latach 2015-2017

\begin{tabular}{|c|c|c|c||}
\hline \hline Rok & $\begin{array}{c}\text { Liczba posiedzeń } \\
\text { plenarnych }\end{array}$ & $\begin{array}{c}\text { Liczba posiedzeń zespo- } \\
\text { lów problemowych }\end{array}$ & $\begin{array}{c}\text { Liczba posiedzeń } \\
\text { prezydium }\end{array}$ \\
\hline 2015 & 1 & 0 & 0 \\
\hline 2016 & 8 & 90 & 12 \\
\hline 2017 & 9 & 76 & 14 \\
\hline
\end{tabular}

Źródło: Opracowanie własne na podstawie Ministerstwo Rodziny, Pracy i Polityki Społecznej, Instytucje dialogu społecznego przy urzędach administracji rządowej. Informator za rok 2016, Biblioteka Dialogu Społecznego, Warszawa 2017, s. 56-93; Ministerstwo Rodziny, Pracy i Polityki Społecznej, Instytucje dialogu społecznego przy urzędach administracji rządowej. Informator za rok 2017, Biblioteka Dialogu Społecznego, Warszawa 2018, s. 59-98.

W latach 2016-2017 Rada zbierała się na posiedzeniach plenarnych 8-9 razy. Rezultat ten był wyższy niż wynik Komisji z lat 2004-2007, 2009-2011 i z 2014 roku. Jedynie w 2002 roku odbyło się więcej posiedzeń plenarnych w ramach Komisji (10 zebrań), niż w ramach Rady. Z niezwykle dużą częstotliwością były organizowane posiedzenia zespołów problemowych Rady (76-90 spotkań). Odbywało się ich nawet 2-krotnie więcej w porównaniu do ich odpowiedników z Komisji (np. w latach 2005-2006 i 2013-2014 doszło zaledwie do 27-36 spotkań zespołów problemowych Komisji). Jedynie w 2003 roku oraz w latach 2008-2009 liczba posiedzeń zespołów problemowych Komisji była zbliżona bądź przewyższała (w tych latach zostało przeprowadzonych 77-100 zebrań) liczbę posiedzeń zespołów problemowych Rady. Na tle Komisji Rada wypadała najgorzej w przypadku częstotliwości zebrań prezydium. 5-krotnie liczba posiedzeń prezydium Komisji (w latach 2002-2004 oraz w 2006 i 2008 roku doszło do 18-28 zebrań) zdecydowanie przeważała nad liczbą posiedzeń prezydium Rady (12-14 zebrań). Z drugiej strony można wyróżnić okres działania Komisji (2010-2011, 2013-2014), kiedy to liczba posiedzeń jej prezydium była 2-krotnie mniejsza (5-8 spotkań), niż liczba posiedzeń prezydium Rady. Warto zaznaczyć, że w pracach Komisji od 26 czerwca 2013 roku do momentu likwidacji tej instytucji w 2015 roku nie uczestniczyli przedstawiciele stro- 
ny związkowej ${ }^{3}$. Analizując dane dotyczące liczby posiedzeń organów Komisji w latach 2013-2015 należy mówić zatem o dialogu dwustronnym (strona pracodawców - rząd), a nie trójstronnym.

Bez wątpienia, na bazie przedstawionych w tabeli 1 i 2 danych można stwierdzić, że w ramach Rady, a także przez wiele lat funkcjonowania Komisji (zwłaszcza w latach 2002-2004, 2007-2009 oraz w 2012 roku) partnerzy społeczni mieli możliwość częstego, bezpośredniego kontaktu z członkami rządu i tym samym wywierania wpływu na jego politykę.

W tabeli 3 wymieniono najczęściej rozpatrywane sprawy podczas posiedzeń plenarnych Komisji i Rady. W tym miejscu trzeba wyjaśnić, dlaczego w artykule skoncentrowano się na analizie kwestii poruszanych na posiedzeniach plenarnych tych instytucji. To właśnie w ich trakcie były podejmowane uchwały Komisji/Rady, a także (w Radzie) wspólne uchwały stron pracowników i pracodawców. W artykule nie było potrzeby dokładniejszego badania prac zespołów problemowych i prezydium Komisji oraz Rady, ponieważ najważniejsze efekty prac tych ciał były dyskutowane na posiedzeniach plenarnych.

Tabela 3

Najczęściej rozpatrywane sprawy na posiedzeniach plenarnych Komisji i Rady

\begin{tabular}{|c|c|}
\hline $\begin{array}{c}\text { Najczęściej poruszane sprawy } \\
\text { na posiedzeniach plenarnych Komisji }\end{array}$ & $\begin{array}{c}\text { Najczęściej poruszane sprawy } \\
\text { na posiedzeniach plenarnych Rady }\end{array}$ \\
\hline $\begin{array}{l}\text { Strategiczne dokumenty rządowe, projekt ustawy budże- } \\
\text { towej, wysokość płacy minimalnej, system ubezpieczeń } \\
\text { społecznych, prawo pracy, sytuacja finansowa przedsię- } \\
\text { biorstw prywatnych, proces prywatyzacji przedsiębiorstw } \\
\text { państwowych, poziom wynagrodzeń w sferze budżetowej, } \\
\text { wysokość rent i emerytur, ochrona zdrowia, projekt pak- } \\
\text { tu społecznego „Pakt dla Pracy i Rozwoju”, projekt umo- } \\
\text { wy społecznej „Gospodarka - Praca - Rodzina - Dialog”, } \\
\text { system podatkowy, polityka spójności Unii Europejskiej, } \\
\text { reforma systemu emerytalnego, Pakiet Działań Antykry- } \\
\text { zysowych, polityka klimatyczno-energetyczna, reforma } \\
\text { szkolnictwa wyższego, bieżąca sytuacja na rynku pracy. }\end{array}$ & $\begin{array}{l}\text { Strategiczne dokumenty rządowe, prawo } \\
\text { pracy, system podatkowy, prawo zamówień } \\
\text { publicznych, polityka klimatyczno-energe- } \\
\text { tyczna, ochrona zdrowia, projekt ustawy bu- } \\
\text { dżetowej, wysokość rent i emerytur, zmiany } \\
\text { w systemie oświaty, bieżąca sytuacja na rynku } \\
\text { pracy, polityka spójności Unii Europejskiej, } \\
\text { wysokość płacy minimalnej, system ubez- } \\
\text { pieczeń społecznych, poziom wynagrodzeń } \\
\text { w sferze budżetowej, reforma systemu eme- } \\
\text { rytalnego. }\end{array}$ \\
\hline
\end{tabular}

Źródło: Opracowanie własne na podstawie: archiwalna strona internetowa Komisji, http://www.dialog.gov. pl/archiwum/trojstronna-komisja-ds-spoleczno-gospodarczych/, 29.01.2019 i strona internetowa Rady http:// www.dialog.gov.pl/dialog-krajowy/rada-dialogu-spolecznego/, 29.01.2019.

Zebrane w tabeli 3 informacje wskazują, że wiele kwestii rozpatrywanych na posiedzeniach plenarnych Komisji było również podejmowane przez Radę. W przypadku części z nich obie instytucje były zobowiązane przepisami prawa do poddania ich analizie na swym forum (chodzi m.in. o projekt ustawy budżetowej czy też wysokość płacy minimalnej). Warto odnotować, że przedmiotem rozmów Komisji i Rady były także kluczowe projekty społeczno-ekonomiczne kolejnych rządów (np. reforma systemu emerytalnego czy też zmiany w prawie pracy) oraz najważniejsze wyzwania, przed

${ }^{3}$ Bojkot Komisji przez związki zawodowe był formą protestu wobec wprowadzonych przez rząd zmian mających na celu uelastycznienie prawa pracy (Czarzasty, 2015). 
którymi stała polska gospodarka (np. sytuacja na rynku pracy, polityka spójności Unii Europejskiej czy też polityka klimatyczno-energetyczna).

Rada nie zajmowała się częścią kwestii będących przedmiotem zainteresowania Komisji, ponieważ w latach 2015-2017 nie miały one istotnego znaczenia dla polskiej gospodarki. Dobrym tego przykładem była często poruszana na forum Komisji kwestia sytuacji finansowej przedsiębiorstw prywatnych. W trakcie ogólnoświatowego kryzysu finansowego, który dosięgnął Polskę w latach 2009-2010, sprawa ta była postrzegana za poważny problem dla dalszego rozwoju Polski, który musiał być rozpatrzony przez instytucję dialogu społecznego. Partnerzy społeczni oraz rząd nie widzieli potrzeby podnoszenia tej kwestii w okresie bardzo dobrej koniunktury gospodarczej, który przypadał na lata funkcjonowania Rady.

Zasadnicza różnica między Komisją i Radą w zakresie analizowanych na ich forum spraw dotyczyła paktów społecznych. W ramach Komisji 2-krotnie podjęto się prób zawarcia tego rodzaju porozumienia, tj. w 2003 („,Pakt dla Pracy i Rozwoju”) i w 2006 roku (umowa społeczna „Gospodarka - Praca - Rodzina - Dialog”). Zakończyły się one niepowodzeniem. W 2003 roku NSZZ „Solidarność” zablokował porozumienie uznając je za niekorzystne dla strony pracowników (Gardawski, 2009, s. 190-195). W 2006 roku rząd zrezygnował z negocjowania umowy społecznej po pojawieniu się oporu ze strony pracodawców wobec wstępnych propozycji rządowych, na rzecz dwustronnego porozumienia z NSZZ „Solidarność” (do którego jednak nie doszło) (Gardawski, 2009, s. 204).

Dodatkowo, w 2009 roku w ramach dialogu autonomicznego strony pracowników i pracodawców uzgodniły program działań mających na celu przeciwdziałanie skutkom ogólnoświatowego kryzysu finansowego, zwany Pakietem Działań Antykryzysowych. W trakcie posiedzenia plenarnego Komisji rząd zobowiązał się do wdrożenia porozumienia w życie (Czarzasty, 2009). Ostatecznie zdecydował się jedynie na jego częściową implementację. Odmówił wprowadzenia tych elementów umowy, które były korzystne dla strony pracowników (Olejnik, 2012, s. 97).

Nie ulega wątpliwości, że działania Komisji w zakresie przygotowywania i implementacji paktów społecznych w latach 2002-2015 zakończyły się porażką. Z drugiej strony, trzeba zaznaczyć, że w ramach Rady nie były prowadzone negocjacje nad paktami społecznymi bądź innymi kompleksowymi porozumieniami na wzór Pakietu Działań Antykryzysowych. Bez wątpienia poziom złożoności prac w Radzie był niższy niż w Komisji. Można zatem uznać, że wprowadzenie zasady rotacyjnego przewodzenia Radzie miało jedynie wymiar symboliczny i nie poprawiło jakości funkcjonowania dialogu społecznego w Polsce. Zarówno pierwszy przewodniczący Rady (Piotr Duda z NSZZ Solidarność), jak i jego następczyni (Henryka Bochniarz z Konfederacji „Lewiatan”) nie byli w stanie przekonać rządu do rozpoczęcia prac nad całościowymi porozumieniami społecznymi. Ich rola została ograniczona do kierowania posiedzeniami plenarnymi i prezydium Rady, nie zdołali oni natomiast wpłynąć na jej agendę programową.

Komisja oraz Rada mogły przyjmować uchwały w każdej sprawie społeczno-gospodarczej, a także podejmować uchwały o charakterze organizacyjnym, mające na celu usprawnienie sposobu działania tych instytucji. W tabeli 4 i 5 zostały zamieszczone dane dotyczące liczby trójstronnych uchwał przyjętych przez te organy. 
Liczba uchwal przyjętych przez Komisję w latach 2002-2015

\begin{tabular}{|c|c|c|c|}
\hline Rok & $\begin{array}{c}\text { Liczba uchwal } \\
\text { w sprawach spoleczno- } \\
\text {-gospodarczych }\end{array}$ & $\begin{array}{c}\text { Liczba uchwal w spra- } \\
\text { wach organizacyjnych }\end{array}$ & $\begin{array}{c}\text { Suma wszystkich } \\
\text { uchwal }\end{array}$ \\
\hline 2002 & 5 & 7 & 12 \\
\hline 2003 & 8 & 3 & 11 \\
\hline 2004 & 0 & 1 & 1 \\
\hline 2005 & 0 & 2 & 2 \\
\hline 2006 & 1 & 1 & 1 \\
\hline 2007 & 1 & 0 & 3 \\
\hline 2008 & 2 & 1 & 2 \\
\hline 2009 & 1 & 1 & 0 \\
\hline 2010 & 2 & 4 & 0 \\
\hline 2011 & 0 & 0 & 0 \\
\hline 2012 & 0 & 0 & 0 \\
\hline 2013 & 0 & 0 & $\mathbf{4 0}$ \\
\hline 2014 & 0 & 0 & 0 \\
\hline 2015 & 0 & $\mathbf{2 0}$ & \\
\hline Razem & $\mathbf{2 0}$ & \multicolumn{2}{l}{} \\
\hline
\end{tabular}

Źródło: Opracowanie własne na podstawie: strona internetowa Komisji, http://www.dialog.gov.pl/archiwum/trojstronna-komisja-ds-spoleczno-gospodarczych, 29.01.2019.

Tabela 5

Liczba uchwał przyjętych przez Radę w latach 2015-2017

\begin{tabular}{|l|c|c|c|}
\hline Rok & $\begin{array}{c}\text { Liczba uchwal } \\
\text { w sprawach społeczno- } \\
\text {-gospodarczych }\end{array}$ & $\begin{array}{c}\text { Liczba uchwal w spra- } \\
\text { wach organizacyjnych }\end{array}$ & $\begin{array}{c}\text { Suma wszystkich } \\
\text { uchwal }\end{array}$ \\
\hline 2015 & 0 & 7 & 7 \\
\hline 2016 & 1 & 10 & 11 \\
\hline 2017 & 0 & 5 & 5 \\
\hline Razem & $\mathbf{1}$ & $\mathbf{2 2}$ & $\mathbf{2 3}$ \\
\hline
\end{tabular}

Źródło: Opracowanie własne na podstawie: strona internetowa Rady, http://www.dialog.gov.pl/dialog-krajowy/rada-dialogu-spolecznego/, 29.01.2019.

Zebrane w tabeli 4 i 5 dane pozwalają stwierdzić, że zarówno Rada, jak i Komisja były nieskutecznymi instytucjami w zakresie uzgadniania porozumień trójstronnych. O całkowitej porażce można mówić w przypadku Rady, w ramach której między 2015-2017 rokiem została przyjęta tylko 1 uchwała w sprawach społeczno-gospodarczych (Uchwała $\mathrm{nr} 16 \mathrm{w}$ sprawie stosowania w sektorze zamówień publicznych prawa korzystnego dla rynku pracy). Rząd Szydło traktował Radę jako miejsce, na forum którego będzie jedynie informował związki zawodowe i organizacje pracodawców o swoich decyzjach politycznych. Nie był zainteresowany włączaniem tych organizacji do procesu decyzyjnego - stąd sprzeciw co do przyjmowania kolejnych trójstronnych uchwał w sprawach społeczno-gospodarczych, które zmuszałyby go do brania na siebie dodatkowych zobowiązań wobec partnerów społecznych. W związku z powyższym można stwierdzić, że zmiana trybu podejmowania decyzji w Radzie zakładająca odejście od zasady jednomyślności w głosowaniu w przypadku strony pracowników i pracodawców nie wywarła 
wpływu na efektywność działania Rady w zakresie przyjmowania uchwał trójstronnych. Ich niewielka liczba była bowiem spowodowana niechęcią rządu do uchwalania tych dokumentów.

Komisja odnosiła znaczące sukcesy w obszarze uzgadniania porozumień trójstronnych jedynie w latach 2002-2003. W tym okresie przyjęła ona 13 uchwał w kwestiach społeczno-gospodarczych. Większość (10) uchwał dotyczyło rządowych projektów ustaw, 3 z nich odnosiły się zaś do ustawowych obowiązków Komisji. Kolejne 12 lat funkcjonowania Komisji (2004-2015) można określić jako czas stracony z punktu widzenia zawierania porozumień trójstronnych. W tym okresie Komisja podjęła niemal 2 razy mniej (tylko 7) uchwał w sprawach społeczno-gospodarczych, niż w latach 2002-2003. Dotyczyły one przede wszystkim ustawowych obowiązków Komisji i nie obejmowały najważniejszych zmian społeczno-gospodarczych wprowadzanych przez kolejne rządy.

W latach 2015-2017 Rada, a w latach 2002-2003 Komisja przyjęły wiele uchwał w sprawach organizacyjnych (Komisja podjęła 10, a Rada 22 takie uchwały). Duża ich liczba wydaje się być w pełni zrozumiała biorąc pod uwagę fakt, że były to pierwsze lata funkcjonowania obu instytucji (Komisja rozpoczęła na nowo działalność wraz z wejściem w życie ustawy o Komisji w 2001 roku. Od 2004 roku liczba uchwał organizacyjnych przyjętych przez Komisję drastycznie spadła). Casus Rady pokazuje, że wysoka aktywność organu korporatystycznego w sprawach organizacyjnych nie musi przynosić pozytywnych rezultatów w zakresie uzgadniania polityki gospodarczej na jego forum.

W przeciwieństwie do Komisji, w ramach Rady strony pracowników i pracodawców dysponują dodatkowymi narzędziami pozwalającymi im na wywieranie wpływu na rząd w obszarze prowadzonej przez niego polityki społeczno-gospodarczej. Mowa tutaj o możliwości przyjmowania dwustronnych uchwał przez strony pracowników i pracodawców. Tabela 6 zawiera dane dotyczące liczby dwustronnych uchwał powziętych przez partnerów społecznych z podziałem na uchwały opiniodawcze i uchwały inicjujące proces polityczny.

Tabela 6

Liczba dwustronnych uchwał przyjętych przez strony pracowników i pracodawców w ramach Rady w latach 2015-2017

\begin{tabular}{|c|c|c|c||}
\hline Rok & $\begin{array}{c}\text { Liczba uchwal } \\
\text { opiniodawczych }\end{array}$ & $\begin{array}{c}\text { Liczba uchwal inicjujących } \\
\text { proces polityczny }\end{array}$ & $\begin{array}{c}\text { Suma wszystkich } \\
\text { uchwal }\end{array}$ \\
\hline 2015 & 0 & 0 & 0 \\
\hline 2016 & 20 & 1 & 21 \\
\hline 2017 & 32 & 2 & 34 \\
\hline Razem & $\mathbf{5 2}$ & $\mathbf{3}$ & $\mathbf{5 5}$ \\
\hline
\end{tabular}

Źródło: Opracowanie własne na podstawie: strona internetowa Rady, http://www.dialog.gov.pl/dialog-krajowy/rada-dialogu-spolecznego/, 22.01.2019.

W latach 2015-2017 strony pracowników i pracodawców przyjęły 55 dwustronnych uchwał, spośród których aż 52 stanowiły uchwały opiniodawcze. Uchwały opiniodawcze głównie przyjmowały krytyczny charakter w stosunku do polityki rządu. W najlepszym przypadku rząd udzielał na nie odpowiedzi, w których przedstawiał alternatywne stanowisko wobec opinii partnerów społecznych wyrażonych w tych uchwałach. Tego 
rodzaju wymiana zdań nie wywierała wpływu na decyzje polityczne władz państwowych. Warto odnotować, że rząd często nie liczył się z uchwałami opiniodawczymi i nawet nie odpowiadał na uwagi wystosowane w nich pod jego kierunkiem (Rada Dialogu Społecznego, 2018, s. 91-92).

W ramach Rady w latach 2015-2017 zostały podjęte 3 uchwały inicjujące proces polityczny. W 2 przypadkach dotyczyły one przygotowanych razem przez strony pracowników i pracodawców projektów ustaw (Uchwała nr $18 \mathrm{w}$ sprawie projektu zmiany ustawy z dnia 26 czerwca 1974 r. - Kodeks pracy oraz Uchwała nr 51 w sprawie rekomendacji zmian $\mathrm{w}$ finansowaniu kształcenia osób niepełnosprawnych w ramach kwalifikacyjnych kursów zawodowych), natomiast w 1 wspólnego zapytania do przedstawiciela rządu (Uchwała $\mathrm{nr} 44 \mathrm{w}$ sprawie zapytania kierowanego do Ministra Zdrowia). Rząd pozytywnie rozpatrzył 2 pierwsze uchwały, za pośrednictwem których partnerzy społeczni zgłosili własne projekty polityczne. Zdecydował się nadać im bieg legislacyjny, a następnie wprowadzić je w życie (Rada Dialogu Społecznego, 2018, s. 92; Rada Ministrów, 2017). Trzecia z uchwał inicjujących proces polityczny pozostała bez odpowiedzi ze strony rządu (Rada Dialogu Społecznego, 2018, s. 91).

Związki zawodowe i organizacje pracodawców popełniły błąd nie decydując się na przyjmowanie większej liczby uchwał inicjujących proces polityczny. Strony pracowników i pracodawców mogą w nich m.in. załączać własne projekty bądź też poprawki do projektów ustaw zawierające regulacje, które nie były rozpatrywane przez Radę Ministrów. W ten sposób partnerzy społeczni mogą zapobiegać powstawaniu aktów prawnych, które będą uderzać w ich interesy polityczne. $Z$ drugiej strony, poprzez uchwały opiniodawcze związki zawodowe i organizacje pracodawców publicznie krytykują politykę władz. Rządowi trudno jest zaś wycofać się ze swoich projektów, ponieważ zostanie to potraktowane przez opinię publiczną za jego porażkę. Siłą rzeczy uchwały opiniodawcze nie mają takiej samej mocy sprawczej jak uchwały inicjujące proces polityczny.

Fakt przyjęcia zaledwie 3 uchwał inicjujących proces polityczny świadczy o tym, że strony pracowników i pracodawców nie wykorzystały dobrej sytuacji finansowej, w jakiej znajdowała się Rada na rzecz poprawienia jakości dialogu społecznego w Polsce. Nie przeznaczyły środków finansowych z jej budżetu na sfinansowanie pomocy eksperckiej, umożliwiającej opracowanie co najmniej kilkunastu projektów ustaw, które następnie byłyby przedkładane Radzie Ministrów poprzez uchwały inicjujące proces polityczny. Nie ulega zatem wątpliwości, że nadanie Radzie własnego budżetu nie zwiększyło efektywności funkcjonowania tego organu w zakresie uzgadniania wspólnej polityki gospodarczej.

\section{Podsumowanie}

Rada jest instytucją, w ramach której partnerzy społeczni spotykali się równie często bądź częściej niż w ramach Komisji. W większości przypadków podczas posiedzeń plenarnych Rady były poruszane te same zagadnienia społeczno-gospodarcze, co w trakcie posiedzeń plenarnych Komisji (np. projekt ustawy budżetowej, wysokość płacy minimalnej, prawo pracy, polityka spójności Unii Europejskiej). W tym zakresie można odnotować 1 relewantną przewagę Komisji nad Radą. W przeciwieństwie do Rady w ra- 
mach Komisji odbywały się prace nad paktami społecznymi. W związku z tym można stwierdzić, że poziom złożoności prac w Komisji był wyższy niż w Radzie. Warto odnotować, że rotacyjny model kierowania Radą nie zmienił tego stanu rzeczy. W pierwszych 2 latach funkcjonowania Rady jej przewodniczącymi byli przedstawiciele związków zawodowych i organizacji pracodawców. Nie zdołali oni przekonać rządu do tego, że istnieje potrzeba rozpoczęcia prac nad kompleksowymi porozumieniami trójstronnymi, mającymi na celu wyznaczenie kierunków rozwoju gospodarczego Polski. Okazało się, że dla efektywności działania organu korporatystycznego nie ma znaczenia to, czy przewodzi mu przedstawiciel partnerów społecznych, czy też strony rządowej.

Trzeba podkreślić, że sam fakt systematycznie odbywających się negocjacji trójstronnych nad wieloma kwestiami społeczno-gospodarczymi nie oznaczał, że dialog społeczny przynosił pozytywne rezultaty. Podczas posiedzeń Rady i Komisji partnerzy społeczni jedynie wymieniali się swoimi stanowiskami, nie dochodzili zaś do porozumienia. Między 2004 a 2015 rokiem Komisja, a w latach 2015-2017 Rada przyjęły odpowiednio 7 (czyli średnio 1 uchwałę na 2 lata) oraz 1 uchwałę w sprawach społeczno-gospodarczych. W artykule wykazano zatem, że Rada w okresie działania rządu Szydło była równie nieefektywną instytucją co Komisja (z wyjątkiem lat 2002-2003. Wówczas Komisja przyjęła 13 uchwał w sprawach społeczno-gospodarczych), mimo że ustawa o Radzie wprowadzała zmiany w systemie głosowania ułatwiające przyjmowanie przez nią uchwał.

Decyzja ustawodawcy o nadaniu Radzie własnego budżetu również nie przyniosła spodziewanych skutków w zakresie zwiększenia poziomu profesjonalizacji i efektywności działania partnerów społecznych. Związki zawodowe i organizacje pracodawców powinny były przeznaczać środki z budżetu Rady m.in. na przygotowanie projektów ustaw, które następnie mogłyby przekazywać Radzie Ministrów do rozpatrzenia w postaci uchwał inicjujących proces polityczny. Należy zaznaczyć, że uchwały te są najważniejszymi instrumentami, jakimi dysponują partnerzy społeczni w ramach ustawy o Radzie, pozwalającymi im na zwiększenie swojego zaangażowania w proces stanowienia i implementacji prawa. Organizacje te przyjęły jednak tylko 3 uchwały inicjujące proces polityczny w latach 2015-2017 (partnerzy społeczni przyjęli także w ramach Rady 52 uchwały opiniodawcze. W zdecydowanej większości przypadków nie wywarły one wpływu na politykę rządu). Można zatem uznać, że partnerzy społeczni nie potrafili skorzystać z przywilejów nadanych Radzie, którymi nie cieszyła się Komisja w latach 2002-2015.

Rząd Beaty Szydło - podobnie jak zdecydowana większość rządów Polski w latach 2002-2015 - w sposób arbitralny podejmował decyzje polityczne. Opowiadał się za prowadzeniem dialogu społecznego ze względów pijarowych - żeby zachować wśród obywateli wizerunek gabinetu otwartego na opinie różnych grup społecznych. Warto podkreślić, że same organizacje należące do Rady (m.in. ZP BCC, OPZZ i FZZ) wielokrotnie wyrażały niezadowolenie ze sposobu funkcjonowania instytucji. Uważały one, że rząd pozoruje dialog z partnerami społecznymi, a negocjacje odbywające się na forum Rady w rzeczywistości mają charakter fasadowy i przypominają najgorsze praktyki funkcjonowania Komisji (ZP BCC, 2017, FZZ, 2018, OPZZ, 2017).

Nie ulega zatem wątpliwości, że w okresie działania rządu Szydło dominującym systemem formułowania polityki w Polsce pozostał PR korporatyzm. Wzmocnienie kom- 
petencji organu korporatystycznego nie spowodowało poprawy jakości dialogu społecznego w Polsce, nie mówiąc o transformacji systemu formułowania polityki w kierunku zachodnioeuropejskiego korporatyzmu.

\section{Bibliografia}

Bernaciak M. (2013), Social dialogue revival or 'PR corporatism'? Negotiating anti-crisis measures in Poland and Bulgaria, "Transfer: European Review of Labour and Research", vol. 19, nr 2.

Chodubski A. (2006), Wstęp do badań politologicznych, Wydawnictwo Uniwersytetu Gdańskiego, Gdańsk.

Czarzasty J. (2009), Government accepts anti-crisis package submitted by social partners, https:// www.eurofound.europa.eu/publications/article/2009/government-accepts-anti-crisis-packagesubmitted-by-social-partners, 22.01.2019.

Czarzasty J. (2015), Poland: National-level tripartite social dialogue back on track, https://www.eurofound.europa.eu/publications/article/2015/poland-national-level-tripartite-social-dialogueback-on-track, 29.01.2019.

Donaghey J., Teague P. (2005), The persistence of social pacts in Europe, "Industrial Relations Journal", vol. 36, nr 6 .

Forum Związków Zawodowych (2018), Wspólne pismo FZZ i ZNP skierowane do Minister Anny Zalewskiej, http://fzz.org.pl/aktualnosci/wspolne-pismo-fzz-znp-skierowane-minister-annyzalewskiej/, 29.01.2019.

Gardawski J. (2009), Dialog społeczny w Polsce. Teoria, historia, praktyka, Ministerstwo Pracy i Polityki Społecznej, Katedra Socjologii Ekonomicznej SGH, Warszawa.

Gardawski J. (2014), Social dialogue reaches critical juncture, https://www.eurofound.europa.eu/publications/article/2014/social-dialogue-reaches-critical-juncture, 22.01.2019.

Herbut R. (2003), Polityka artykulacji i reprezentacji interesów grupowych, w: Administracja i polityka. Ewolucja stosunków przemystowych w Europie Środkowej i Wschodniej, red. J. Sroka, Wydawnictwo Uniwersytetu Wrocławskiego, Wrocław.

Ministerstwo Pracy i Polityki Społecznej (2014), Trójstronna Komisja do Spraw Społeczno-Gospodarczych. Informator za rok 2013, Biblioteka Dialogu Społecznego, Warszawa.

Ministerstwo Pracy i Polityki Społecznej (2015), Instytucje dialogu społecznego przy urzędach administracji rzadowej. Informator za rok 2014, Biblioteka Dialogu Społecznego, Warszawa.

Ministerstwo Rodziny, Pracy i Polityki Społecznej (2017), Instytucje dialogu społecznego przy urzędach administracji rzadowej. Informator za rok 2016, Biblioteka Dialogu Społecznego, Warszawa.

Ministerstwo Rodziny, Pracy i Polityki Społecznej (2018), Instytucje dialogu społecznego przy urzędach administracji rządowej. Informator za rok 2017, Biblioteka Dialogu Społecznego, Warszawa.

Ogólnopolskie Porozumienie Związków Zawodowych (2017), Fasadowy dialog, http://www.opzz.org. pl/opinie-i-analizy/opinie-i-analizy-opzz/zdaniem-zwiazkowca/fasadowy-dialog, 29.01.2019.

Olejnik M. (2012), Trójstronna Komisja ds. Społeczno-Gospodarczych w latach 2001-2011. Funkcjonowanie i analiza skuteczności, w: Inercja czy rozwój dialogu społecznego w Polsce? Generalia i detale, red. R. Wiszniowski, Związek Pracodawców „Polska Miedź”, Lubin.

Olejnik M. (2017), Korporatystyczny system formułowania polityki w państwach Grupy Wyszehradzkiej. Zmiana paradygmatu, Wydawnictwo Nauka i Innowacje, Poznań.

Ost D. (2010), Illusory Corporatism in Eastern Europe: Neoliberal Tripartism and Postcommunist Class Identieties, "Warsaw Forum of Economic Sociology", vol. 1, nr 2. 
Rada Dialogu Społecznego (2018), Sprawozdanie z działalności Rady Dialogu Społecznego za rok 2017, Warszawa.

Rada Ministrów (2017), Wniosek dotyczacy uchwaly nr 18 strony pracowników i pracodawców Rady Dialogu Społecznego z 19 października 2016 r. w sprawie projektu zmiany ustawy z 26 czerwca 1974 r. Kodeks pracy, https://www.premier.gov.pl/wydarzenia/decyzje-rzadu/wniosekdotyczacy-uchwaly-nr-18-strony-pracownikow-i-pracodawcow-rady.html, 29.01.2019.

Strona internetowa Trójstronnej Komisji ds. Społeczno-Gospodarczych, http://www.dialog.gov.pl/archiwum/trojstronna-komisja-ds-spoleczno-gospodarczych/, 29.01.2019.

Strona internetowa Rady Dialogu Społecznego, http://www.dialog.gov.pl/dialog-krajowy/rada-dialogu-spolecznego/, 29.01.2019.

Towalski R. (2011), Dialog społeczny w Europie Środkowej i Wschodniej w procesie integracji europejskiej (na przykładzie krajów Grupy Wyszehradzkiej), Szkoła Główna Handlowa w Warszawie, Oficyna Wydawnicza, Warszawa.

Ustawa z dnia 6 lipca 2001 r. o Trójstronnej Komisji do Spraw Społeczno-Gospodarczych i wojewódzkich komisjach dialogu społecznego, Dz. U. 2001, Nr 100, poz. 1080.

Ustawa z dnia 24 lipca 2015 r. o Radzie Dialogu Społecznego i innych instytucjach dialogu społecznego, Dz. U. 2015, poz. 1240.

Związek Pracodawców Business Centre Club, Posiedzenie Plenarne RDS z udziałem Prezydenta RP, https://www.bcc.org.pl/posiedzenie-plenarne-rds-z-udzialem-prezydenta-rp-2/, 29.01.2019.

\section{Which corporatism in Poland? The Social Dialogue Council in the period of functioning of Beata Szydło's government}

\section{Summary}

Corporatism, understood as a policy making system in which the government, trade unions and employers' organizations collectively make and implement political decisions in the socio-economic matters, functions in many Western European countries. A deformed version of this system - PR (Public Relations) corporatism - emerged in Poland after 1989. Within its framework, the government simulates the tripartite negotiations with social partners to strengthen its political support among the citizens. In fact, it makes political decisions on its own.

The aim of the article was to examine whether creation of the new corporatist organ (The Social Dialogue Council), which has substantially greater competences than its predecessor (The Tripartite Commission for Socio-Economic Matters) led to transformation of the policy-making system in Poland from PR corporatism to Western European corporatism.

The comparative analysis was conducted in this paper in relation to the Council activity during the period of Beata Szydło's government (2015-2017) and the Commission's activity between 2002-2015. The research results revealed that the Council and Commission were equally ineffective social dialogue organs, during assemblies of which no major political decisions were made. The paper indicates that expanding the competences of the corporatist organ does not have to improve the social dialogue's quality. PR corporatism has prevailed in Poland as a policy-making system after 2015.

Key words: corporatism, PR corporatism, The Social Dialogue Council, The Tripartite Commission for Socio-Economic Matters, social partners, government 